\title{
Phenotypic and Genetic Diversity in Strains of Common Blight Bacteria (Xanthomonas campestris pv. phaseoli and X. campestris pv. phaseoli var. fuscans) in a Secondary Center of Diversity of the Common Bean Host Suggests Multiple Introduction Events
}

\author{
Ruth López, Carmen Asensio, and Robert L. Gilbertson
}

First and second authors: Instituto Tecnológico Agrario de Castilla y León, Consejería de Agricultura y Ganadería, Junta de Castilla y León, 47071 Valladolid, Spain; and third author: Department of Plant Pathology, University of California, Davis. Accepted for publication 7 June 2006.

\begin{abstract}
López, R., Asensio, C., and Gilbertson, R. L. 2006. Phenotypic and genetic diversity in strains of common blight bacteria (Xanthomonas campestris pv. phaseoli and X. campestris pv. phaseoli var. fuscans) in a secondary center of diversity of the common bean host suggests multiple introduction events. Phytopathology 96:1204-1213.

Common bacterial blight (CBB) disease of the common bean (Phaseolus vulgaris) is caused by Xanthomonas campestris pv. phaseoli and the brown-pigmented variant $X$. campestris pv. phaseoli var. fuscans. CBB first was described in Castilla y León County, Spain, in 1940, and is now a major constraint on common bean production. In this secondary center of diversity of the common bean, large-seeded Andean cultivars predominate, although medium-seeded Middle American cultivars also are grown. Xanthomonad-like bacteria associated with CBB in Castilla y León were characterized on the basis of carbohydrate metabolism, brown pigment production, genetic analyses (repetitive-element polymerase chain reaction [rep-PCR] and random amplified polymorphic DNA [RAPD]) and pathogenicity on cultivars representing the two common bean gene pools (Andean and Middle American). X. campestris pv. phaseoli was more prevalent (80\%) than X. campestris pv. phaseoli var. fuscans (20\%). Patterns of carbohydrate metabolism of Spanish CBB bacteria were similar

to those of known strains; and only $X$. campestris pv. phaseoli var. fuscans strains utilized mannitol as a sole carbon source. rep-PCR and RAPD analyses revealed relatively little genetic diversity among Spanish $X$. campestris pv. phaseoli strains, and these strains were placed together with New World strains into a large cluster. Similar to other New World strains, representative Spanish X. campestris pv. phaseoli strains were highly pathogenic on bean cultivars of both gene pools, showing no gene pool specialization such as that found in certain East African strains. Genetic analyses and pathogenicity tests confirmed and extended previous results, indicating that these East African strains represent distinct xanthomonads that independently evolved to be pathogenic on common bean. $X$. campestris pv. phaseoli var. fuscans strains were more closely related and genetically distinct from $X$. campestris pv. phaseoli strains. However, two distinct clusters of $X$. campestris pv. phaseoli var. fuscans strains were identified, one having the most New World strains and the other having the most African strains. Spanish strains were placed in both clusters, but all strains tested were highly pathogenic on bean cultivars of both gene pools. Together, our results are consistent with multiple introductions of CBB bacteria into Spain. These findings are discussed in terms of breeding for CBB resistance and the overall understanding of the genetic diversity and evolution of CBB bacteria.
\end{abstract}

Common bean (Phaseolus vulgaris L.) has a New World origin, and domestication occurred within two major geographic locations: Mesoamerica or Middle America (e.g., Mexico and Central America) and Andean South America (e.g., Peru, Bolivia, and northern Argentina) (12). Cultivated varieties of this crop are derived from materials (e.g., landraces) from one of these two locations, and are referred to as being Middle American, Andean, or hybrid bean genotypes. The north-central region of Spain (Castilla y León County) is a secondary center of diversity of the common bean and accounts for the majority of Spanish production of this crop (38). The principal cultivated bean types in this region are large-seeded white kidney beans (e.g., cv. Riñón) of the Andean gene pool, but medium-seeded white and colored types of the Middle American gene pool (mostly great northern and pinto) also are cultivated (38).

Common bacterial blight (CBB) disease first was described in Spain in 1940 (1), and has become a major constraint on common bean production in Castilla y León County. CBB is caused by the seedborne bacteria Xanthomonas campestris (axonopodis) pv.

Corresponding author: R. López; E-mail address: lopperru@ itacyl.es

DOI: 10.1094/PHYTO-96-1204

(C) 2006 The American Phytopathological Society phaseoli and the brown-pigmented variant, X. campestris pv. phaseoli var. fuscans. CBB causes yield losses and reduces the commercial value of seed, particularly under temperature and humidity conditions that favor disease development. Management of CBB is difficult and is based, mainly, on pathogen-free seed and resistant cultivars $(13,50,54)$.

CBB first was described in the late 1800s from the United States, but now is found in most common bean-growing regions of the world $(13,18,50,54)$. Worldwide distribution of the disease can be attributed to efficient long-distance spread in association with seed. However, it is not clear whether this reflects dissemination of a single progenitor CBB population (i.e., a monophyletic population structure) or distinct lineages of xanthomonads that evolved to infect common bean during domestication and spread of this New World crop (i.e., a polyphyletic population structure). Several lines of evidence suggest a polyphyletic population structure for $\mathrm{CBB}$ bacteria. First, X. campestris pv. phaseoli and $X$. campestris pv. phaseoli var. fuscans are distinct xanthomonads based on genetic, pathogenic, and certain biochemical and physiological properties $(5,7,14-16,18-20,26,34,36)$. Second, the pathogenicity of $X$. campestris pv. phaseoli strains varies considerably on common bean germ plasm $(10,35,42-45,48,52)$, and pathogen races have been identified based on reactions on tepary bean ( $P$. acutifolius) lines (53). Finally, strains of $X$. campestris 
pv. phaseoli from East Africa have been identified that are genetically distinct and differentially pathogenic on genotypes of the two common bean gene pools (26). Thus, it appears that CBB is caused by a complex of genetically distinct xanthomonads. However, the relative biological significance of this diversity is not well understood.

The common bean host has a major impact on pathogen genetic diversity. Most notably, there is compelling evidence for hostpathogen co-evolution in the fungal pathogens Colletotrichum lindemuthianum (causal agent of anthracnose) $(3,47)$, Phaeoisariopsis griseola (causal agent of angular leafspot) $(8,17,25,30)$, and Uromyces appendiculatus (causal agent of bean rust) $(31,37)$, in which genetically distinct pathogen genotypes are associated with Andean and Middle American genotypes. Here, pathogen isolates from bean genotypes of one gene pool tend to be more pathogenic on genotypes of that gene pool than on those of the other gene pool. Thus, Andean isolates of P. griseola, C. lindemuthianum, and $U$. appendiculatus are highly pathogenic on Andean genotypes, whereas Middle American isolates are highly pathogenic on Middle American genotypes although, in some cases, these isolates also may be pathogenic on Andean beans (25,30,31). A similar phenomenon has been reported for the genetically distinct East African $X$. campestris pv. phaseoli strains, which are significantly more pathogenic on Andean bean genotypes $(8,26)$.

Members of the genus Xanthomonas exhibit a high phytopathogenic diversity; however, their phenotypic uniformity has made it difficult to investigate their genetic diversity $(34,49)$. Polymerase chain reaction (PCR)-based DNA fingerprinting methods, such as repetitive-element (rep)-PCR (24), provide a practical and effective means to examine genotypic diversity among xanthomonads. Importantly, rep-PCR correlates well with other methods for assessing genetic relatedness in bacteria (e.g., DNA:DNA hybridization) (33). The rep-PCR method has been used to investigate diversity of xanthomonads and other bacteria at the species, pathovar, and subpathovar levels $(22,24,34)$. These studies have revealed that some $X$. campestris pathovars are heterogenous, whereas others appear to be more homogenous $(4,6,23,26,34,49)$. The results of these studies have important practical (in terms of resistance breeding, regulatory issues, and taxonomy) and basic (bacterial evolution) implications.

The objectives of this study were to (i) determine the diversity of CBB bacteria in the north-central part of Spain, an Old World secondary center of diversity of common bean; (ii) compare Spanish CBB strains with those from other geographical regions (e.g., the New World and Africa); and (iii) determine whether Spanish CBB strains show pathogenic specialization (co-evolution) on Andean or Middle American bean genotypes.

\section{MATERIALS AND METHODS}

Bacterial strains and growth conditions. Spanish $X$. campestris pv. phaseoli and X. campestris pv. phaseoli var. fuscans strains used in this study are listed in Table 1. Bacteria were isolated from bean leaf and pod tissues onto yeast dextrose carbonate agar (YDCA) plates (40). For long-term storage, bacteria were maintained in glycerol at $-70^{\circ} \mathrm{C}$. For routine use, strains were maintained as cell suspensions in distilled water at $4^{\circ} \mathrm{C}$, and grown for $48 \mathrm{~h}$ at $28^{\circ} \mathrm{C}$ on YDCA. Strains obtained from other locations are listed in Table 2. These included $X$. campestris pv. phaseoli and $X$. campestris pv. phaseoli var. fuscans strains from the National Collection of Plant-Pathogenic Bacteria (NCPPB; York, UK).

Identification of $X$. campestris pv. phaseoli and $X$. campestris pv. phaseoli var. fuscans strains. Putative strains of CBB bacteria were subjected to standard biochemical and physiological tests, including Gram reaction $(3 \% \mathrm{KOH}$ test), urease and oxidase reactions (BioMérieux), glucose metabolism under aerobic and anaerobic conditions (Hugh-Leifson medium, Sigma Chemical, St. Louis), aesculin hydrolysis, utilization of glycerol as a sole carbon source, casein degradation, reaction in litmus milk me-

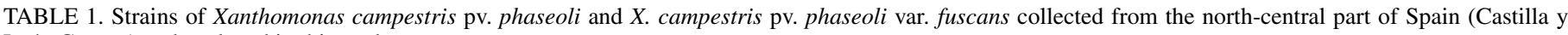
León County) and analyzed in this study

\begin{tabular}{|c|c|c|c|c|}
\hline \multirow[b]{2}{*}{ Strain } & \multirow[b]{2}{*}{ Sample ${ }^{\mathrm{z}}$} & \multirow[b]{2}{*}{ Geographical origin } & \multicolumn{2}{|c|}{$\operatorname{Host}^{\mathrm{y}}$} \\
\hline & & & Bean cultivar & Gene pool \\
\hline \multicolumn{5}{|c|}{ X. campestris pv. phaseoli } \\
\hline SITA558 & $\mathrm{L}$ & Zamadueñas, Valladolid & A52 & Andean \\
\hline SITA586 & $\mathrm{P}$ & Topas, Salamanca & Alba & Andean \\
\hline SITA656 & $\mathrm{L}$ & Sta. Teresa, Salamanca & Arrocina & Middle American \\
\hline SITA658 & $\mathrm{P}$ & Sta. Teresa, Salamanca & Arrocina & Middle American \\
\hline SITA659 & $\mathrm{L}$ & Sta. Teresa, Salamanca & Pinto madrileño & Andean \\
\hline SITA664 & $\mathrm{L}$ & Topas, Salamanca & Pinto madrileño & Andean \\
\hline SITA700 & $\mathrm{L}$ & Zamadueñas, Valladolid & Arrocina & Middle American \\
\hline SITA701 & $\mathrm{P}$ & Zamadueñas, Valladolid & Planchada & Middle American \\
\hline SITA729 & $\mathrm{L}$ & S. Juan de Torres, León & Canela & Andean \\
\hline SITA768 & $\mathrm{P}$ & Zamadueñas, Valladolid & Red mexican & Middle American \\
\hline SITA781 & $\mathrm{P}$ & Serrada, Valladolid & Canellini & Andean \\
\hline SITA785 & $\mathrm{L}$ & Zamadueñas, Valladolid & Cárdeno & Andean \\
\hline SITA808 & $\mathrm{L}$ & Fresno-Alhandiga, Salamanca & Arrocina & Middle American \\
\hline SITA876 & $\mathrm{L}$ & Abrareces de Tera, Zamora & $\ldots$ & $\ldots$ \\
\hline SITA877 & $\mathrm{L}$ & Zamadueñas, Valladolid & Riñón & Andean \\
\hline SITA907 & $\mathrm{P}$ & Galisancho, Salamanca & Plancheta & Middle American \\
\hline SITA908 & $\mathrm{P}$ & Galisancho, Salamanca & Riñón & Andean \\
\hline SITA909 & $\mathrm{L}$ & Sta. Teresa, Salamanca & Canela & Andean \\
\hline SITA910 & $\mathrm{P}$ & Sta. Teresa, Salamanca & Arrocina & Middle American \\
\hline SITA911 & $\mathrm{L}$ & Galisancho, Salamanca & Negra tolosana & Andean \\
\hline SITA921 & $\mathrm{L}$ & Galisancho, Salamanca & Plancheta & Middle American \\
\hline \multicolumn{5}{|c|}{ X. campestris pv. phaseoli var. fuscans } \\
\hline SITA662 & $\mathrm{L}$ & Villafranca, Valladolid & Pinto madrileño & Andean \\
\hline SITA762 & $\mathrm{L}$ & Nava de Arévalo, Ávila & Canellini & Andean \\
\hline SITA780 & $\mathrm{P}$ & Zamadueñas, Valladolid & Red kloud & Andean \\
\hline SITA875 & $\mathrm{L}$ & Sta. Teresa, Salamanca & $\ldots$ & $\ldots$ \\
\hline SITA920 & $\mathrm{L}$ & Fresno, Burgos & Morada & Andean \\
\hline
\end{tabular}

y All strains were collected from Phaseolus vulgaris during surveys conducted from 1996 to 2001 in Spain. ... = not determined.

z Strains were isolated from leaf (L) or pod (P) sample. 
dium, and production of acid from arabinose in Dye's medium $(9,40)$. These strains also were examined for catalase production (9), starch degradation, and nitrate reduction (40). NCPPB strains listed in Table 2 were used as positive controls.

Strains identified as $X$. campestris were characterized further by PCR and pathogenicity tests. Two PCR tests for CBB bacteria were used: (i) a commercially available test from D-Genos (Angers, France) and (ii) a test with the $\mathrm{X} 4 \mathrm{e} / \mathrm{X} 4 \mathrm{c}$-specific primer pair (2). For both PCR tests, the template was $5 \mu \mathrm{l}$ of a cell suspension, prepared by adding a loop of bacteria from a single colony on YDCA into $1 \mathrm{ml}$ of sterile distilled water in a $25-\mu \mathrm{l}$ reaction mixture. PCR parameters were as described by the manufacturer (D-Genos) or by Audy et al. (2) for the X4e/X4c primer pair. PCR products were examined by electrophoresis in $1.5 \%$ agarose gels in Tris-acetate-EDTA (TAE) buffer. Gels were stained in ethidium bromide and nucleic acids visualized with UV light. At least two independent PCRs were performed with each test for each strain.

Pathogenicity on common bean was assessed using two leaf inoculation methods: (i) razor blade inoculation (29) of the Spanish large white kidney cv. Riñón and (ii) water-soaking (41) of the red small-seeded breeding line BAT41 from Centro Internacional de Agricultura Tropical (Cali, Colombia). Inoculum was prepared by growing bacterial strains on YDCA plates for $48 \mathrm{~h}$ at $28^{\circ} \mathrm{C}$ and preparing a cell suspension in sterile distilled water. The cell concentration was adjusted with a Jasco-V-530 spectrophotometer to an optical density of $0.3(600 \mathrm{~nm})$, which corresponds to approximately $10^{8} \mathrm{CFU} / \mathrm{ml}$. A negative control of sterile water also was included in each experiment. The first fully expanded trifoliolate leaf was inoculated, and plants were maintained in a controlled growth chamber $\left(25^{\circ} \mathrm{C}, 12-\mathrm{h}\right.$ photoperiod, and $80 \%$ relative humidity). Disease reactions were recorded 7 to 14 days after inoculation. The pathogenicity of each strain was tested with each method at least three times in independent experiments.

Nutritional characterization. The capacity of Spanish $X$. campestris pv. phaseoli and $X$. campestris pv. phaseoli var. fuscans strains to utilize selected carbohydrates as a sole carbon source was tested. The carbohydrates (D-mannitol, inositol, D-sorbitol, erythritol, L+tartrate, D+tartrate, L-lactate, trehalose, turanose, maltose, saccarose, maleic acid, citric acid, and benzoic acid) were added to Dye's medium (9) to a final concentration of $1 \%$ (wt/vol). Metabolism of each carbohydrate was tested twice for each strain. The known $X$. campestris pv. phaseoli and X. campestris pv. phaseoli var. fuscans strains from NCPPB were used as controls.
rep-PCR analysis. For DNA isolation, bacteria were grown in tubes containing $8 \mathrm{ml}$ of $1 \times$ yeast extract tryptone (YT) medium with slow shaking for $48 \mathrm{~h}$ at $28^{\circ} \mathrm{C}$. Cells were collected by centrifugation and the pellet was washed in $1 \mathrm{ml}$ of NE buffer $(0.15 \mathrm{M} \mathrm{NaCl}$ and $50 \mathrm{mM}$ EDTA). DNA was extracted from pelleted cells as described (26). Total genomic DNA was adjusted to a final concentration of $10 \mathrm{ng} / \mathrm{ml}$ with a TKO100 Fluorometer (Hoefer Scientific).

The rep-PCR was performed as previously described using REP-PCR, ERIC-PCR, and BOX-PCR primers (24,26,32). PCR products were examined by electrophoresis in $1.5 \%$ agarose gels in TAE. Gels were stained in ethidium bromide and nucleic acids visualized with a gel-imaging system (model IS-1000; Alpha Innotech Corporation). Strains were tested at least twice with each rep-PCR method to assure reproducibility of the DNA fingerprints.

Random amplified polymorphic DNA analysis. Bacteria was grown for $24 \mathrm{~h}$ in Luria-Bertani (LB) liquid media and DNA was isolated with a DNA extraction kit (UltraClean; MoBio Laboratories). PCR amplifications were performed in a total volume of $25 \mu \mathrm{l}$ containing $30 \mathrm{ng}$ of total genomic DNA, $0.8 \mu \mathrm{M}$ primer, $0.2 \mathrm{mM}$ each dNTP, $2 \mathrm{mM} \mathrm{MgCl}_{2}, 1 \times$ PCR reaction buffer, and 1.5 U of Taq DNA polymerase (Invitrogen, Life Technologies). Amplifications were carried out in a Perkin-Elmer 980 (PerkinElmer Cetus) with an initial denaturing step of $94^{\circ} \mathrm{C}$ for $5 \mathrm{~min}$; followed by 45 cycles of $94^{\circ} \mathrm{C}$ for $1 \mathrm{~min}, 34^{\circ} \mathrm{C}$ for $1.5 \mathrm{~min}$, and $72^{\circ} \mathrm{C}$ for $2 \mathrm{~min}$; and a final cycle of $72^{\circ} \mathrm{C}$ for $10 \mathrm{~min}$. Random amplified polymorphic DNA (RAPD) products $(15 \mu \mathrm{l})$ were examined by electrophoresis in $1.5 \%$ agarose gels in TAE. Gels were stained in ethidium bromide and nucleic acids visualized with a gel-imaging system (Genegenius Bio Imag. Syst., Singene, UK).

The 20 10-mer primers from Kit $\mathrm{G}$ of Operon Technologies (Alameda, CA) were tested for their capacity to reveal polymorphisms among five representative $X$. campestris pv. phaseoli strains (P1, M11, and T21 and Spanish strains SITA659 and SITA908). In all, 16 primers directed the amplification of reproducible DNA patterns and were used in the RAPD analysis, whereas 4 primers yielded no reproducible bands and were not used. Strains were tested at least three times with each primer to assure reproducibility of the DNA patterns.

Analysis of genetic similarity. To estimate the genetic relationships among strains, a phylogenetic tree was constructed from rep-PCR and RAPD data. Distinct and reproducible bands were scored as present $(=1)$ or absent $(=0)$ to generate a data matrix.

TABLE 2. Other strains of Xanthomonas campestris analyzed in this study

\begin{tabular}{|c|c|c|}
\hline Strain & Geographical origin & Source ${ }^{y}$ \\
\hline \multicolumn{3}{|l|}{ X. campestris pv. phaseoli } \\
\hline NCPPB3035 ${ }^{\mathrm{T}}(\text { ATCC9563) })^{\mathrm{z}}$ & United States & NCPPB \\
\hline NCPPB1646 & Australia & NCPPB \\
\hline M11 & Malawi & R. L. Gilbertson \\
\hline $\mathrm{P} 1$ & Puerto Rico & R. L. Gilbertson \\
\hline $\mathrm{T} 21$ & Tanzania & R. L. Gilbertson \\
\hline \multicolumn{3}{|c|}{ X. campestris pv. phaseoli var. fuscans } \\
\hline NCPPB381 & Canada & NCPPB \\
\hline NCPPB 1402 & Uganda & NCPPB \\
\hline NCPPB 1654 & South Africa & NCPPB \\
\hline NCPPB2665 & Italy & NCPPB \\
\hline $\mathrm{P} 2 \mathrm{~F}$ & Puerto Rico & R. L. Gilbertson \\
\hline $\mathrm{M} 12 \mathrm{~F}$ & Malawi & R. L. Gilbertson \\
\hline \multicolumn{3}{|l|}{ X. campestris pv. vesicatoria } \\
\hline 9964 & United States & R. L. Gilbertson \\
\hline \multicolumn{3}{|l|}{ X. campestris pv. campestris } \\
\hline 4751 & United States & R. L. Gilbertson \\
\hline \multicolumn{3}{|l|}{ X. campestris pv. carotae } \\
\hline $1 \mathrm{H}$ & United States & R. L. Gilbertson \\
\hline
\end{tabular}

y NCPPB = National Collection of Plant-Pathogenic Bacteria, York, UK, and R. L. Gilbertson, Department of Plant Pathology, University of California, Davis.

z Type strain. ATCC $=$ American Type Culture Collection. 
The genetic similarity between two strains was calculated based on Jaccard's coefficient with the SIMQUAL program of NTSYSpc (version 2.10q) (27). The similarity matrix was used to construct a dendrogram with the unweighted pair group arithmetic mean method using the SHAN and TREE programs in NTSYS. Bootstrap analysis of the binary data was performed with the program WinBoot (51).

Differential pathogenicity tests on Andean and Middle American cultivars. To assess pathogenic specialization, selected Spanish X. campestris pv. phaseoli and X. campestris pv. phaseoli var. fuscans strains were inoculated onto six cultivars representing the two major common bean gene pools (26). Andean cultivars were Topcrop and White Kidney from the United States and the Spanish cv. Riñón, whereas Middle American cultivars were Sutter Pink and Black Turtle Soup (BTS) from the United States and the Spanish cv. Arrocina. Inoculum was prepared as previously described and adjusted to $10^{8} \mathrm{CFU} / \mathrm{ml}$. Plants were grown in sterile soil in pots in a greenhouse. The first fully expanded trifoliolate leaf was inoculated with the razor blade method (29). A completely randomized experimental design was used, with each plot consisting of one pot with three plants of a given cultivar. This experiment was repeated three times.

After inoculation, plants were kept in a greenhouse maintained at approximately $30^{\circ} \mathrm{C}$ and 60 to $80 \%$ relative humidity. Symptoms were rated 10 to 12 days after inoculation according to the following rating scale: 1 = no visual symptoms or slight marginal necrosis; 2 = water-soaking, chlorosis, or necrosis (blight) in $<25 \%$ of the inoculated area; $3=25$ to $50 \%$ blight; and $4=>50 \%$ blight. Data was analyzed as a factorial model using the analysis of variance test and means were compared with Duncan's multiple range test (39).

\section{RESULTS}

Identification of Spanish X. campestris pv. phaseoli and $X$. campestris pv. phaseoli var. fuscans strains. Common bean leaves and pods with CBB symptoms were collected from Castilla y León during 1996 to 2001. Strains of putative CBB bacteria were selected based upon having a yellow mucoid colony morphology and being the predominant bacteria isolated from these samples. In all, 26 strains, isolated from some of the most important Andean and Middle American cultivars grown in this region, were selected for further characterization (Table 1). Of these strains, 54\% were isolated from Andean cultivars and 35\% from
Middle American cultivars, whereas the host gene pool of the remaining $11 \%$ was not identified.

The biochemical and physiological properties of these 26 xanthomonad strains generally were consistent with those of the species $X$. campestris and the NCPPB X. campestris pv. phaseoli and $X$. campestris pv. phaseoli var. fuscans strains (data not shown). An exception to the $X$. campestris profile was the inability of most of the Spanish strains to grow on arabinose as a sole carbon source; however, this also was observed for most of the NCPPB CBB strains, including the $X$. campestris pv. phaseoli type strain (NCPPB3035). The type strain also did not utilize glycerol or produce acid from litmus milk; this is in contrast to the Spanish strains, the other NCPPB CBB strains, and the $X$. campestris species profile. Approximately $20 \%$ (5 of 26) of the Spanish $X$. campestris strains produced a brown diffusible pigment on YDCA media, suggesting that they were $X$. campestris pv. phaseoli var. fuscans.

Definitive evidence that all 26 Spanish $X$. campestris strains were CBB bacteria came from results of PCR and pathogenicity tests. The diagnostic approximately 200- and 700-bp DNA fragments were amplified from all 26 strains by PCR with the D-Genos and X4e/X4c primers, respectively. All 26 strains also induced typical CBB symptoms (watersoaking, chlorosis, and necrosis) when inoculated onto trifoliolate leaves of cvs. Riñón and BAT41. Together with the brown pigment production results, these 26 strains were identified as $X$. campestris pv. phaseoli or $X$. campestris pv. phaseoli var. fuscans (Table 1).

Nutritional characterization. Examination of the carbohydrate assimilation profiles (Table 3 ) revealed differences between strains of $X$. campestris pv. phaseoli and $X$. campestris pv. phaseoli var. fuscans as well as differences among strains of these bacteria. The Spanish and NCPPB X. campestris pv. phaseoli var. fuscans strains utilized mannitol and trehalose, respectively, as sole carbon sources, whereas all or most of the X. campestris pv. phaseoli strains did not utilize these substrates. Conversely, all of the $X$. campestris pv. phaseoli strains, except the type strain, used maltose as a sole carbohydrate source, whereas all but one of the $X$. campestris pv. phaseoli var. fuscans strains did not utilize this substrate (Table 3 ). In general, there was more variability in carbohydrate utilization among $X$. campestris pv. phaseoli strains compared with $X$. campestris pv. phaseoli var. fuscans strains (Table 3 ).

rep-PCR analysis. Based upon results of previous rep-PCR studies of $\mathrm{CBB}$ bacteria, strains $\mathrm{P} 1$ and $\mathrm{P} 2 \mathrm{~F}$ were selected to represent large groups of New World $X$. campestris pv. phaseoli

TABLE 3. Carbohydrate assimilation profiles generated for Xanthomonas campestris pv. phaseoli and X. campestris pv. phaseoli var. fuscans strains

\begin{tabular}{|c|c|c|c|c|c|c|c|}
\hline \multirow[b]{3}{*}{ Substrate } & \multirow[b]{3}{*}{ NCPPB3035 } & \multicolumn{6}{|c|}{ Number of strains ${ }^{\mathrm{V}}$} \\
\hline & & \multicolumn{4}{|c|}{ X. campestris pv. phaseoli ${ }^{\mathrm{w}}$} & \multicolumn{2}{|c|}{ X. campestris pv. phaseoli var. fuscans } \\
\hline & & 16 & 2 & 3 & 1 & 8 & 1 \\
\hline D-Mannitol & - & - & - & - & - & + & + \\
\hline D-Sorbitol & - & - & - & - & - & - & - \\
\hline L-Lactate & - & - & - & - & - & - & - \\
\hline Erytritol & - & - & - & - & - & - & - \\
\hline L-Tartrate & - & - & - & - & - & - & - \\
\hline D-Tartrate & - & - & - & - & - & - & - \\
\hline Inositol & - & - & - & - & - & - & - \\
\hline Trehalose & - & - & - & + & + & + & + \\
\hline Turanose & - & - & - & - & - & - & - \\
\hline Maltose & - & + & $t^{\mathrm{z}}$ & + & + & - & $+^{\mathrm{z}}$ \\
\hline Saccarose & $+^{\mathrm{z}}$ & + & + & + & + & + & - \\
\hline Maleic acid & - & - & - & - & - & - & - \\
\hline Citric acid & - & - & + & - & $t^{\mathrm{z}}$ & - & - \\
\hline Benzoic acid & - & - & - & - & - & - & - \\
\hline
\end{tabular}


and $X$. campestris pv. phaseoli var. fuscans strains, respectively. Strains T21 and M11 were selected to represent the genetically diverse $X$. campestris pv. phaseoli strains from East Africa, and strain M12F was selected as a representative East African X. campestris pv. phaseoli var. fuscans strain (26).

The rep-PCR fingerprints generated with all three primers revealed little or no genetic diversity among the Spanish $X$. campestris pv. phaseoli strains, strain P1 (representing the New World strains), and strains from Australia (NCPPB1646) and the United States (NCPPB3035, type strain) (Fig. 1A, B, and C). In some cases, a few polymorphic fragments differentiated some strains. For example, with REP-PCR, strain NCPPB1646 had two additional fragments of approximately 2 and $6 \mathrm{~kb}$ (Fig. 1A, lane 15); with BOX-PCR, NCPPB1646 and NCPPB3035 differed from the other strains by the absence of an approximately $1.5-\mathrm{kb}$ fragment (Fig. 1B, lanes 14 and 15); and with ERIC-PCR, an additional approximately 1.6-kb fragment was detected in strains P1, NCPPB3035, and the Spanish strains SITA808 and SITA909 (Fig. $1 \mathrm{C}$, lanes 1, 5, 10, and 14).

REP, BOX, and ERIC-PCR fingerprints of the East African $X$. campestris pv. phaseoli strains (M11 and T21) and strains of $X$. campestris pv. campestris, X. campestris pv. carotae, and $X$. campestris pv. vesicatoria were distinct from those of the other $X$. campestris pv. phaseoli strains (Fig. 1A, B, and C). The ERICPCR and REP-PCR fingerprints of strains M11 and T21 also were distinct, whereas those generated by BOX-PCR were similar (Fig. $1 \mathrm{~A}, \mathrm{~B}$, and $\mathrm{C}$ ).
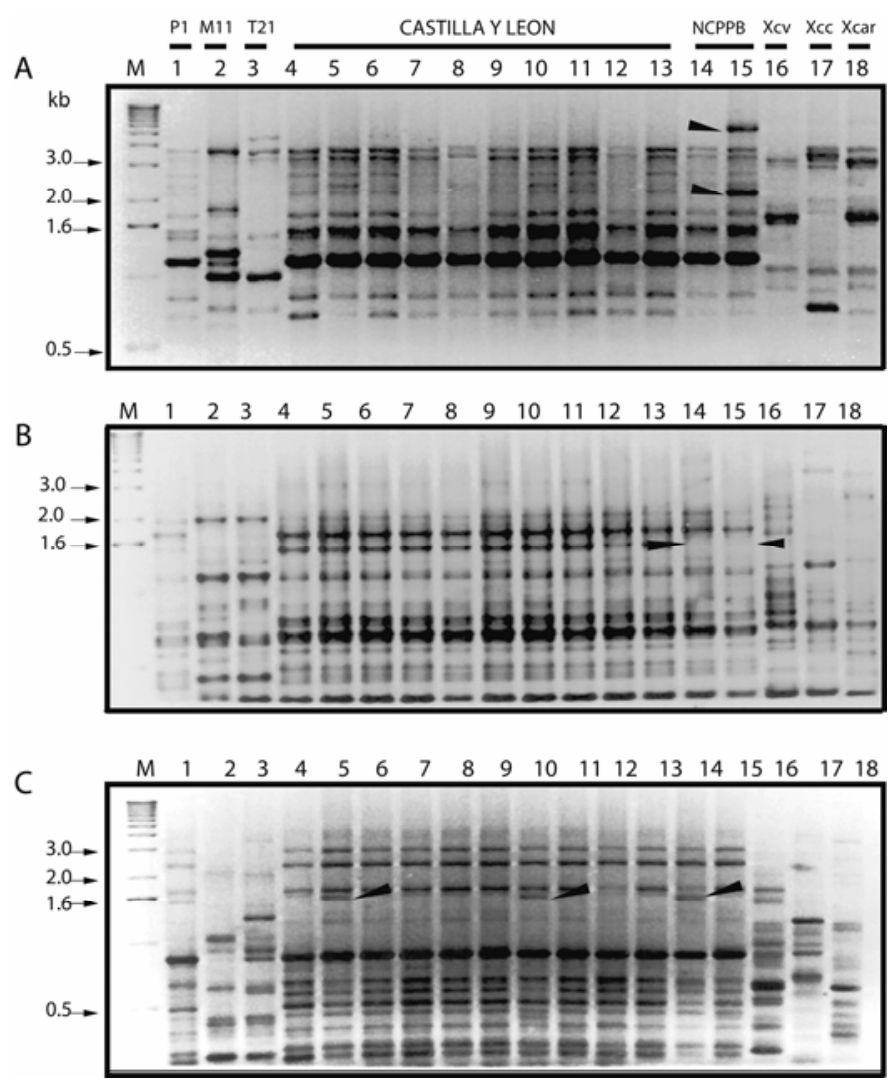

Fig. 1. DNA fingerprint patterns generated from total DNA from Xanthomonas campestris pv. phaseoli strains by A, REP-PCR, B, BOX-PCR, and $\mathbf{C}$, ERIC-PCR. Repetitive-element polymerase chain reaction products were analyzed by electrophoresis in 1.5\% agarose gels. Lanes 1 to 3 : X. campestris pv. phaseoli strains $\mathrm{P} 1, \mathrm{M} 11$, and $\mathrm{T} 21$ from Puerto Rico, Malawi, and Tanzania, respectively; lanes 4 to 13: representative $X$. campestris pv. phaseoli strains from Castilla y León; lanes 14 to 15: NCPPB3035 (type strain) and NCPPB1646 strain from Australia; lanes 16 to 18: X. campestris pathovars: vesicatoria $(\mathrm{Xcv})$, campestris $(\mathrm{Xcc})$, and carotae (Xcar). First lane is the $1-\mathrm{kb}$ ladder size marker (M; Gibco BRL). Arrows indicate selected similarities or differences between patterns as indicated in the text.
As expected, the REP, BOX, and ERIC-PCR fingerprints of $X$. campestris pv. phaseoli var. fuscans strains were readily distinguished from those of $X$. campestris pv. phaseoli strains and strains of the other $X$. campestris pathovars (Fig. 2A, B, and C). An interesting exception was with BOX-PCR, in which the fingerprints of the East African $X$. campestris pv. phaseoli strains (M11 and T21) were similar to those of $X$. campestris pv. phaseoli var. fuscans strains (Fig. 2B). The REP-PCR and BOX-PCR fingerprints of the $X$. campestris pv. phaseoli var. fuscans strains were very similar (Fig. 2A and B). ERIC-PCR fingerprints also were similar, but some differences were observed. Strain P2F, the representative New World strain, was differentiated from M12F, the representative East African strain, by an additional approximately $2.2-\mathrm{kb}$ fragment and the lack of a 1.2-kb fragment (Fig. 2C, lanes 1 and 2). The ERIC-PCR fingerprint of Spanish strain SITA780 was similar to that of strain P2F (Fig. 2C, lanes 2 and 5), whereas those of strains SITA662, SITA762, SITA875, and SITA920 were similar to that of strain M12F (Fig. 2C, lanes 1, 3, 4, 5, and 7). The fingerprint of Spanish strain SITA875 was a combination between those of $\mathrm{P} 2 \mathrm{~F}$ and $\mathrm{M} 12 \mathrm{~F}$ in having both the approximately $1.2-\mathrm{kb}$ fragment and the $2.2-\mathrm{kb}$ fragment (Fig. $2 \mathrm{C}$, lanes 1, 2, and 6). ERIC-PCR fingerprints generated for the NCPPB strains (from Canada, Italy, South Africa, and Uganda) were similar to that of strain M12F.

RAPD analysis. The RAPD patterns generated with each of the 16 primers differentiated the East African X. campestris pv. phaseoli strains $\mathrm{M} 11$ and $\mathrm{T} 21$ from the other strains (P1,

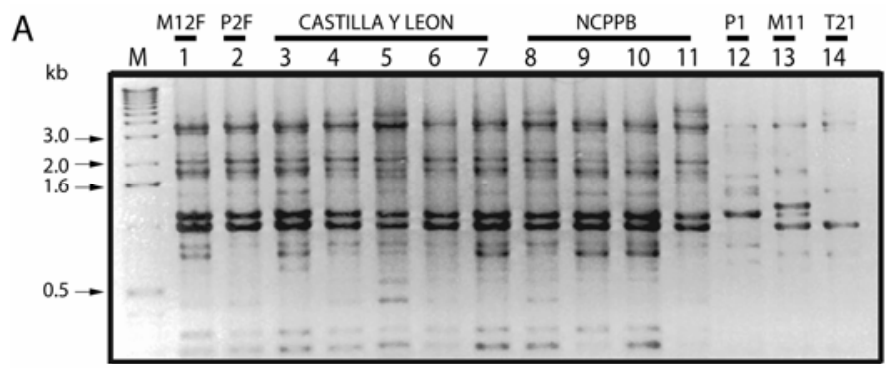

B
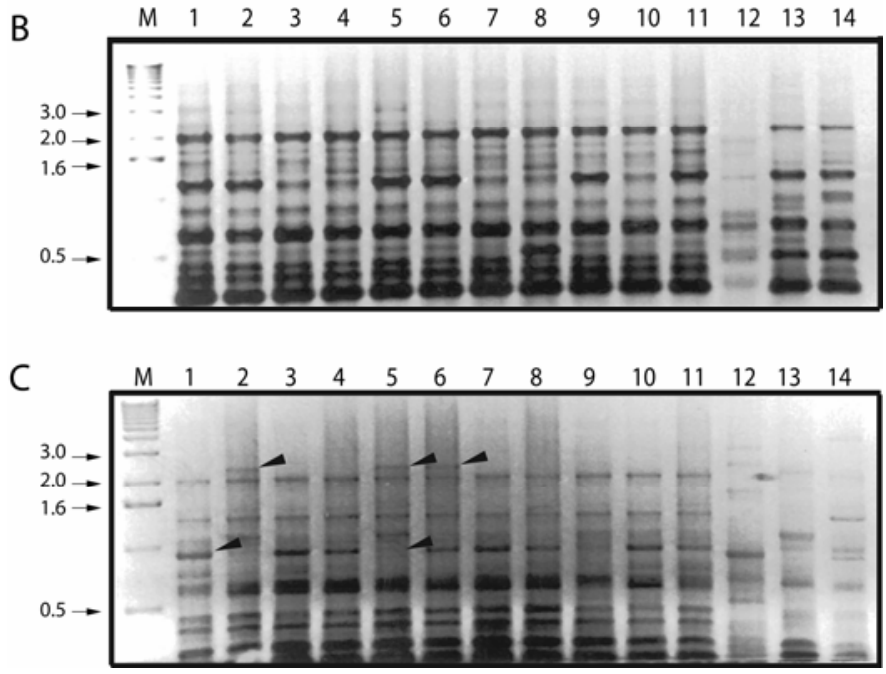

Fig. 2. DNA fingerprint patterns generated from total DNA from Xanthomonas campestris pv. phaseoli var. fuscans strains by A, REP-PCR, B, BOXPCR, and C, ERIC-PCR. Repetitive-element polymerase chain reaction products were analyzed by electrophoresis in $1.5 \%$ agarose gels. Lanes 1 to 2 : $\mathrm{M} 12 \mathrm{~F}$ and $\mathrm{P} 2 \mathrm{~F} X$. campestris pv. phaseoli var. fuscans strains from Malawi and Puerto Rico, respectively; lanes 3 to 7: representative X. campestris pv. phaseoli var. fuscans strains from Castilla y León; lanes 8 to 11: X. campestris pv. phaseoli var. fuscans strains from the NCPPB collection; lanes 12 to 14: $X$. campestris pv. phaseoli strains P1, M11, and T21, respectively. First lane is the 1-kb ladder size marker (M; Gibco BRL). Arrows indicate similarities or differences between patterns as indicated in the text. 
SITA659, and SITA908). However, only two primers, OPG-4 and OPG-10, revealed polymorphisms among the non-East African strains. Thus, only these primers were used in RAPD analysis of all CBB strains. The RAPD patterns generated with the OPG-10 primer were very similar for all $X$. campestris pv. phaseoli strains, with one additional fragment detected in some Spanish strains (Fig. 3A). In contrast, RAPD analysis with the OPG-4 primer revealed distinct patterns for the non-East African X. campestris pv. phaseoli strains P1, NCPPB1646, and NCPPB3035; and five different patterns were identified for the 21 Spanish strains (Fig. 3B).

As with the ERIC-PCR, RAPD analysis with the OPG-10 primer revealed distinct patterns for the New World (P2F) and East African (M12F) X. campestris pv. phaseoli var. fuscans strains (Fig. 3A). The pattern of Spanish strain SITA780 was similar to that of P2F, whereas the patterns of the other Spanish strains were more similar to that of M12F (data not shown). Polymorphisms also were detected among the four NCPPB X. campestris pv. phaseoli var. fuscans strains. In contrast to the situation with $X$. campestris pv. phaseoli strains, RAPD patterns generated for $X$. campestris pv. phaseoli var. fuscans strains with the OPG-4 primer were similar (Fig. 3B; data not shown).

Cluster analysis. A dendrogram was generated using 73 discrete bands generated in the rep-PCR and RAPD analyses (Fig. 4). The non-East African X. campestris pv. phaseoli and all $X$. campestris pv. phaseoli var. fuscans strains were placed into two distinct clusters (similarity coefficient of approximately $20 \%$ and supported by high bootstrap values [ $>80 \%]$ ), consistent with the high level of genetic diversity between these CBB bacteria.
The non-East African X. campestris pv. phaseoli strain cluster included all Spanish strains (overall similarity coefficient of $70 \%$ and supported by a bootstrap value of $100 \%$ ). A number of clusters having more closely related strains were identified, particularly one with strains SITA808, SITA809, and NCPPB303 (Fig. 4). The East African X. campestris pv. phaseoli strains, M11 and T21, were placed in the $X$. campestris pv. phaseoli var. fuscans strain cluster (Fig. 4). However, they clearly were genetically distinct from each other and from the $X$. campestris pv. phaseoli var. fuscans strains (similarity coefficients of approximately 52 and $20 \%$, respectively). X. campestris pv. phaseoli var. fuscans strains were placed into two clusters that were supported by a high bootstrap value $(72.5 \%)$ (Fig. 4). One cluster contained the New World P2F and Spanish SITA780 strains (New World strain cluster), whereas the other contained strains from Africa (Malawi, South Africa, and Uganda), Canada, Spain (four strains), and Italy (African strain cluster).

Differential pathogenicity tests on Andean and Middle American cultivars. For these experiments, Spanish CBB strains representing the genetic diversity identified in the rep-PCR and RAPD analyses (Fig. 4) were selected. For Spanish X. campestris pv. phaseoli, SITA659 represented the most prevalent strain, and strains SITA808 and SITA909 represented the most genetically diverse. For X. campestris pv. phaseoli var. fuscans, SITA920 represented the most prevalent strain from the large strain cluster and SITA875 represented the most genetically diverse strain from this cluster, whereas SITA780 represented the other cluster (Fig. 4). Control X. campestris pv. phaseoli strains were P1 (New World

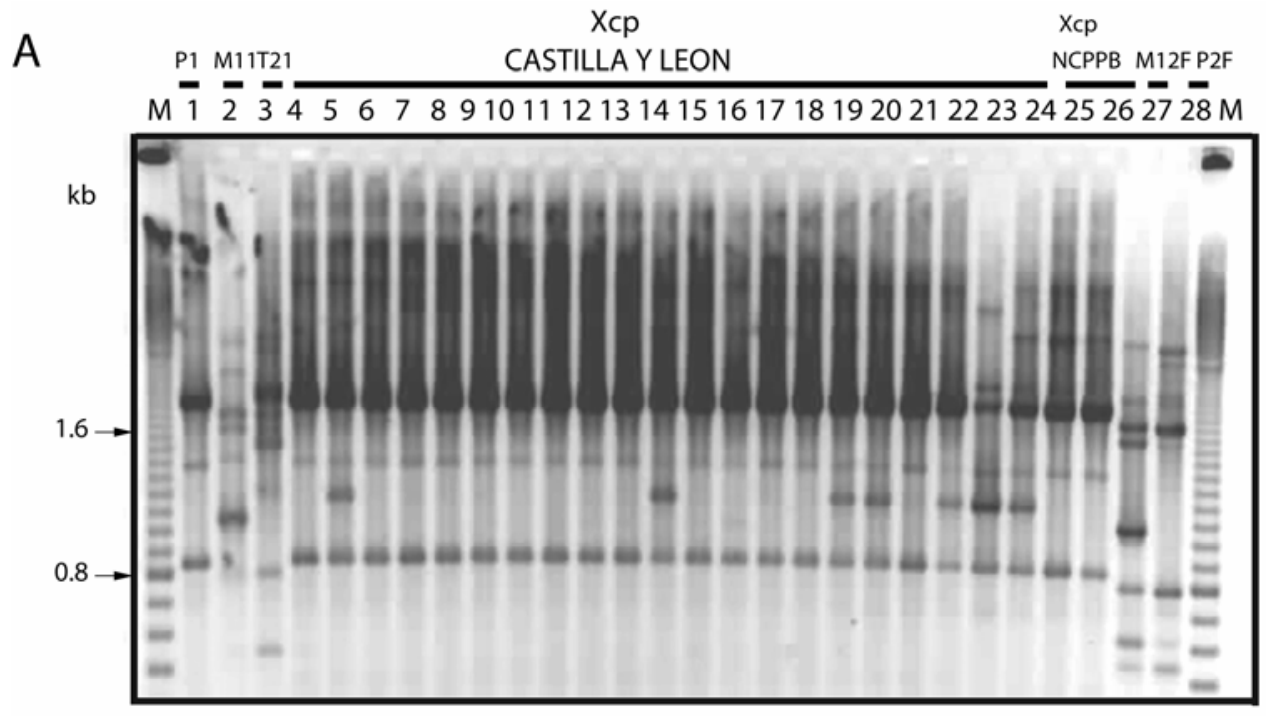

B M $\quad$ M 2345678910111213141516171819202122232425262728 M

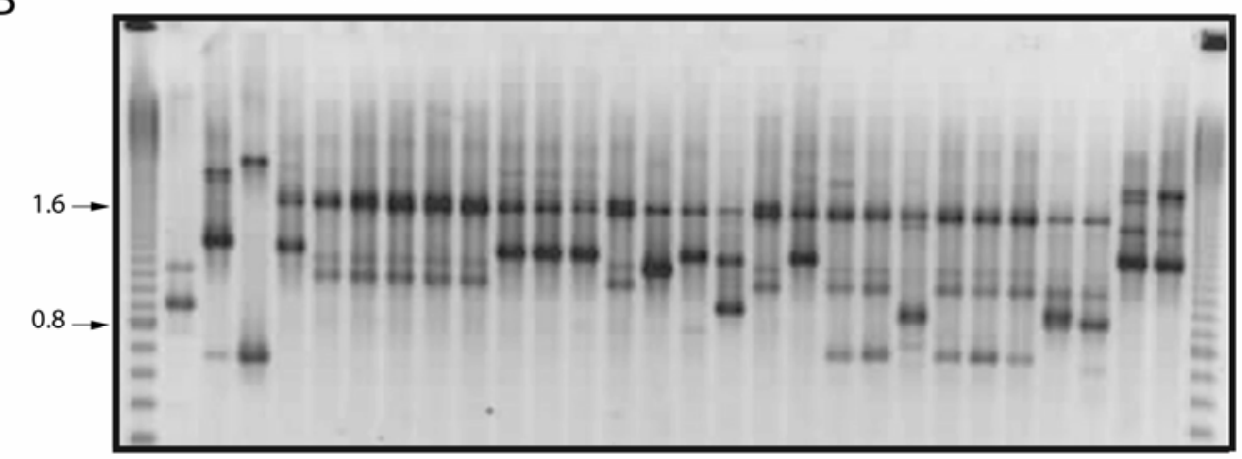

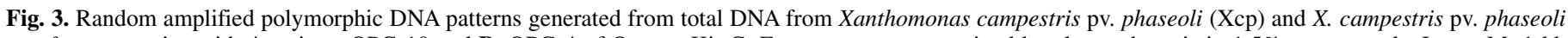

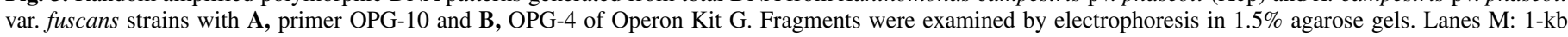

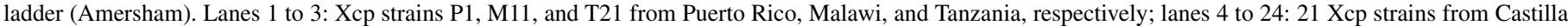

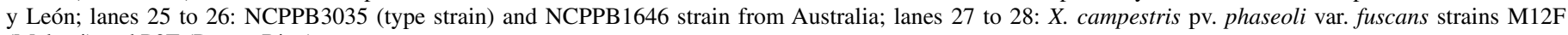
(Malawi) and P2F (Puerto Rico). 
strain cluster) and M11 (East African strain), and control X. campestris pv. phaseoli var. fuscans strains were P2F (New World strain cluster) and M12F (African strain cluster).

The results of these experiments are presented in Tables 4 and 5. Consistent with previous results, the East African $X$. campestris pv. phaseoli strain M11 was significantly less pathogenic on the Middle American cvs. BTS and Sutter Pink (mean disease ratings [MDRs] of 1.2 to 1.3 ) compared with the New World strain P1 (MDR of 3.3 to 4.0 ), whereas both strains were highly pathogenic on Andean cultivars (MDRs of 2.7 to 3.8). M11 also was significantly less pathogenic on the Spanish Middle American cv. Arrocina (MDR of 1.5) compared with the Andean cv. Riñón (MDR of 3.8).

All three Spanish $X$. campestris pv. phaseoli strains were highly pathogenic on Middle American cultivars (MDRs of 3.3 to 4.0) and moderately to highly pathogenic on Andean cultivars (MDRs of 2.5 to 4.0). Some pathogenic variability was detected among Spanish strains (Table 4). For example, strain SITA659 was the least pathogenic, particularly on Andean cv. White Kidney (MDR of 2.5), whereas SITA909 and SITA808 were highly pathogenic on cultivars of both gene pools (Table 4).
All $X$. campestris pv. phaseoli var. fuscans strains were highly pathogenic on Andean and Middle American cultivars (Table 5). Spanish strains SITA780 and SITA920 were less pathogenic on Andean cultivars (especially cv. Topcrop) compared with the other strains, whereas SITA780 and SITA920 were highly pathogenic on Middle American cultivars, especially cv. Arrocina (Table 5).

\section{DISCUSSION}

Northern Spain represents an interesting system to study the genetic diversity and host-pathogen interaction of CBB bacteria because it is a secondary center of common bean diversity, where types of both gene pools are grown (38). This system also provides an opportunity to apply new molecular fingerprinting methods together with biochemical, physiological, and pathogenicity tests to assess pathogen diversity from an Old World location, thereby complimenting information from other geographical areas (i.e., various New World locations and Africa) (26).

$X$. campestris pv. phaseoli and $X$. campestris pv. phaseoli var. fuscans are causal agents of CBB in Spain, but X. campestris pv.

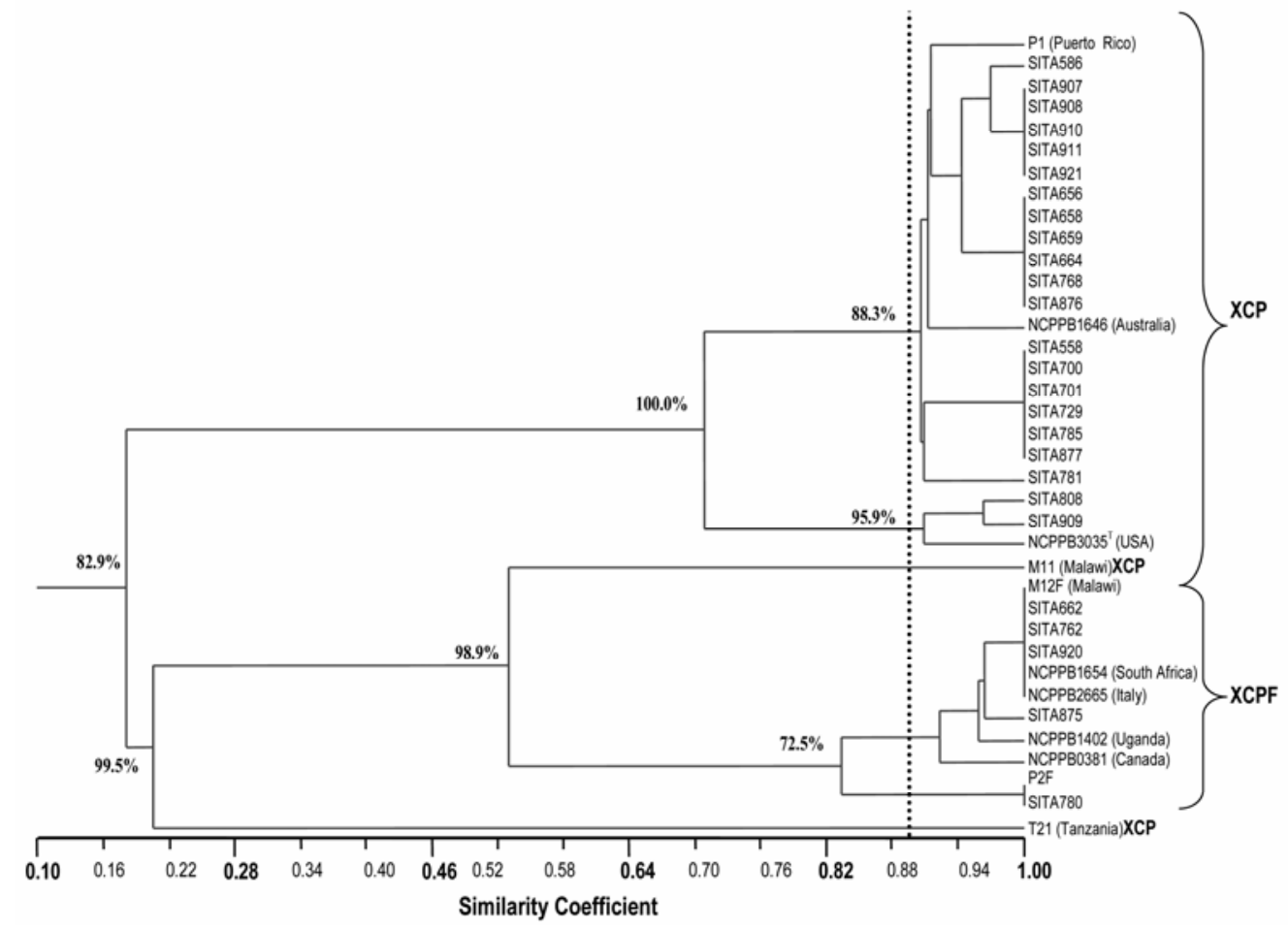

Fig. 4. Dendrogram constructed from repetitive-element polymerase chain reaction and random amplified polymorphic DNA data generated with total DNA from strains of Xanthomonas campestris pv. phaseoli (XCP) and X. campestris pv. phaseoli var. fuscans (XCPF). NCPPB3035 ${ }^{\mathrm{T}}$ : type strain. Bootstrap confidence measures $(>50 \%)$ from 1,000 bootstrap replicates are indicated.

TABLE 4. Mean disease ratings for Xanthomonas campestris pv. phaseoli strains inoculated onto six common bean cultivars representing the two gene pools of Phaseolus vulgaris

\begin{tabular}{|c|c|c|c|c|c|}
\hline \multirow[b]{2}{*}{ Cultivar } & \multicolumn{5}{|c|}{ Strain $^{z}$} \\
\hline & SITA909 & P1 & SITA808 & SITA659 & M11 \\
\hline \multicolumn{6}{|l|}{ Andean } \\
\hline Riñón & $4.0 \mathrm{a}$ & $3.8 \mathrm{ab}$ & $4.0 \mathrm{a}$ & $3.7 \mathrm{ab}$ & $3.8 \mathrm{ab}$ \\
\hline White Kidney & $3.5 \mathrm{abc}$ & $3.8 \mathrm{ab}$ & $3.6 \mathrm{ab}$ & $2.5 \mathrm{~d}$ & $3.4 a b c$ \\
\hline \multicolumn{6}{|l|}{ Middle American } \\
\hline Black Turtle Soup & $3.9 \mathrm{ab}$ & $4.0 \mathrm{a}$ & $3.7 \mathrm{ab}$ & $3.8 \mathrm{ab}$ & $1.2 \mathrm{e}$ \\
\hline
\end{tabular}

${ }^{\mathrm{z}}$ Rating scale: 1 = no visual symptoms or slight marginal necrosis; $2=$ watersoaking, chlorosis, or necrosis (blight) in $<25 \%$ of the inoculated area; $3=25$ to $50 \%$ blight; and $4=>50 \%$ blight; means with the same letter are not significantly $(P<0.01)$ different (Duncan's multiple range test). 
phaseoli was most prevalent. Biochemical and physiological tests identified xanthomonad-like bacteria to genus and species (X. campestris), but PCR and pathogenicity tests provided the definitive evidence that these strains were CBB bacteria. $X$. campestris pv. phaseoli and X. campestris pv. phaseoli var. fuscans strains were differentiated based upon brown pigment production; however, these bacteria also were distinguished based on utilization of mannitol. Previous studies have reported that $X$. campestris pv. phaseoli var. fuscans can utilize this substrate, whereas $X$. campestris pv. phaseoli is negative or variable $(36,44)$. It also has been reported that, compared with $X$. campestris pv. phaseoli, strains of $X$. campestris pv. phaseoli var. fuscans are more pathogenic or aggressive on common bean $(9,10,28,36)$ and can be pathogenic on cowpea (Vigna unguiculata) $(28,36)$. Given that brown pigment production apparently is not involved in pathogenicity of $X$. campestris pv. phaseoli var. fuscans $(21,44)$, it is possible that the capacity to utilize mannitol or some other substrate is. Overall, our results support previous studies indicating that biochemical and physiological tests are not very useful for differentiating legume-infecting xanthomonads at the subspecies level $(9,21,36,44)$.

Combining molecular fingerprinting methods (especially repPCR) with biological properties (e.g., pathogenicity, bacteriophage sensitivity, and so on) provides a robust means of identifying and investigating the significance of subspecies variability in plant-pathogenic xanthomonads $(4,6,11,26,32-34,46)$. This multiphasic approach provided several lines of evidence showing that Spanish X. campestris pv. phaseoli strains were more similar to New World strains than to the genetically distinct East African strains. First, little variability among Spanish strains was revealed by rep-PCR or RAPD analyses, and these strains all were placed in single large cluster that included representative New World strains. Second, like the strains from the New World, Spanish $X$. campestris pv. phaseoli strains showed no pathogenic specialization on either the common bean gene pool (i.e., they were isolated from and were highly pathogenic on cultivars of both gene pools). Though closely related, Spanish $X$. campestris pv. phaseoli strains were not clonal, because some genetic and pathogenic variability was detected. This is fully consistent with previous studies of genetic and pathogenic variability in this pathogen $(10,28,35,42-45,48,52)$. The high level of variability revealed by RAPD analysis with primer OPG-4 may be due to the targeting of a hypervariable region, such as a repetitive element $(14,15,26)$.

Our results extended the large New World cluster of $X$. campestris pv. phaseoli strains into the Old World, and did not reveal the presence of the genetically distinct East African strains in Spain. The pathogenic specialization of the East African strains was proposed to reflect a co-evolution process between the pathogen (an introduced or indigenous progenitor) and Andean gene pool types which predominate in this geographic region (12). In the Spanish cropping system, Andean, Middle American, and local recombinant cultivars are grown (38); this likely would select for CBB bacteria that infect bean cultivars of both gene pools. Taken together, our results suggest that $X$. campestris pv. phaseoli populations in Spain were derived from a New World progenitor or progenitors, probably introduced in association with seed.

Although Spanish $X$. campestris pv. phaseoli and $X$. campestris pv. phaseoli var. fuscans strains were highly pathogenic on bean cultivars of both gene pools, they were readily differentiated by rep-PCR and RAPD analyses, consistent with results of previous studies $(5,7,14,15,19,20,26)$. A recent comprehensive analysis of the genus Xanthomonas based upon rep-PCR, considered with results of analyses based on other properties, provides a framework in which to evaluate the significance of subspecies genetic variability within this group of bacteria $(34,49)$. In this analysis, $X$. campestris pv. phaseoli and X. campestris pv. phaseoli var. fuscans were placed in distinct subclusters within a single large cluster (the proposed species X. axonopodis). Moreover, the genetic distances separating these subclusters were equivalent to those separating distinct pathovars, consistent with the hypothesis that $X$. campestris pv. phaseoli and $X$. campestris pv. phaseoli var. fuscans are distinct pathovars or species. From an evolutionary perspective, the collective evidence suggests that these are distinct xanthomonads that arose, via parallel evolution, to be pathogenic on common bean or other legumes.

The rep-PCR method involves the use of primers that anneal within repetitive elements in the bacterial genome and direct the amplification of a complex pattern or fingerprint of DNA fragments $(24,32)$. Each rep-PCR primer or primer pair (e.g., REP, ERIC, and BOX) anneals to different elements and, thus, directs the amplification of a distinct compliment of DNA fragments (24). Moreover, different results can be obtained depending on the rep-PCR primers used $(33,34)$. In the present study, ERIC-PCR revealed a higher level of genetic diversity than REP- or BOXPCR. In particular, genetic diversity revealed among $X$. campestris pv. phaseoli var. fuscans strains by ERIC-PCR contributed to the identification of two distinct clusters of strains containing New World or African strains (Fig. 4). Spanish X. campestris pv. phaseoli var. fuscans strains were represented in both clusters, which may suggest multiple introductions of the pathogen into Spain. However, the overall low level of genetic diversity detected among these strains and their similar pathogenicity properties indicate that $X$. campestris pv. phaseoli var. fuscans is more homogenous (i.e., monophyletic) than $X$. campestris pv. phaseoli (i.e., polyphyletic). These results also demonstrate the importance of using all three rep-PCR approaches in the assessment of genetic diversity.

The results of this study confirm and extend those of Mkandawire et al. (26) demonstrating the existence of genetically and pathogenically distinct strains of $X$. campestris pv. phaseoli in East Africa (e.g., M11 and T21). The cluster analysis supported the hypothesis that these strains represent distinct xanthomonads that independently evolved to be pathogenic on common bean or other legumes, rather than having evolved from a New World

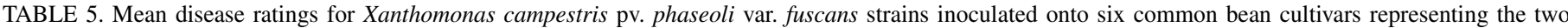
gene pools of Phaseolus vulgaris

\begin{tabular}{|c|c|c|c|c|c|}
\hline \multirow[b]{2}{*}{ Cultivar } & \multicolumn{5}{|c|}{ Strain ${ }^{z}$} \\
\hline & SITA875 & $\mathrm{M} 12 \mathrm{~F}$ & $\mathrm{P} 2 \mathrm{~F}$ & SITA780 & SITA920 \\
\hline \multicolumn{6}{|l|}{ Andean } \\
\hline Riñón & $3.9 \mathrm{abc}$ & $4.0 \mathrm{a}$ & $4.0 \mathrm{a}$ & $4.0 \mathrm{a}$ & $3.2 \mathrm{~d}$ \\
\hline Topcrop & $3.9 \mathrm{abc}$ & $4.0 \mathrm{a}$ & $3.9 \mathrm{abc}$ & $3.3 \mathrm{bcd}$ & $3.3 \mathrm{bcd}$ \\
\hline White Kidney & $3.6 \mathrm{abcd}$ & $3.9 \mathrm{abc}$ & $3.8 \mathrm{abc}$ & $3.5 \mathrm{abcd}$ & $3.5 \mathrm{abcd}$ \\
\hline \multicolumn{6}{|l|}{ Middle American } \\
\hline Black Turtle Soup & $3.8 \mathrm{abc}$ & $3.9 \mathrm{abc}$ & $3.7 \mathrm{abcd}$ & $3.8 \mathrm{abc}$ & $3.4 \mathrm{abcd}$ \\
\hline Arrocina & $4.0 \mathrm{a}$ & $3.5 \mathrm{abcd}$ & $4.0 \mathrm{a}$ & $4.0 \mathrm{a}$ & $4.0 \mathrm{a}$ \\
\hline Sutter Pink & $3.9 \mathrm{abc}$ & $3.8 \mathrm{abc}$ & $3.7 \mathrm{abcd}$ & $3.8 \mathrm{abc}$ & $3.8 \mathrm{abc}$ \\
\hline
\end{tabular}

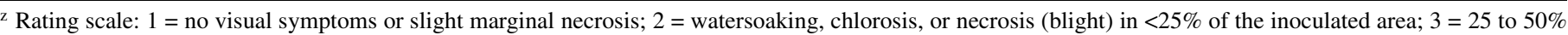
blight; and $4=>50 \%$ blight; means with the same letter are not significantly $(P<0.01)$ different (Duncan's multiple range test). 
$X$. campestris pv. phaseoli progenitor. This polyphyletic model also seems more consistent with the host specialization of the East African strains (26) (Table 4), because it seems unlikely that a hypothetical New World $X$. campestris pv. phaseoli progenitor would have lost pathogenicity on Middle American bean cultivars. However, the origin, nature, and taxonomy of these strains (i.e., are they strains of $X$. campestris pv. phaseoli or distinct pathovars or species?) will require further study.

The genetic diversity and phenotypic properties of $\mathrm{CBB}$ in Spain suggest multiple introduction events into this secondary center of common bean diversity. These findings contribute to our overall understanding of the worldwide population structure and evolution of this important seedborne pathogen, and will help identify appropriate CBB strains for disease resistance breeding.

\section{ACKNOWLEDGMENTS}

This research was supported with grant RTA01-005-C2 from the Spanish Instituto Nacional de Investigación y Tecnología Agraria y Alimentaria (INIA). R. López was funded by a fellowship from the Consejería de Agricultura y Ganadería, Junta de Castilla y León.

\section{LITERATURE CITED}

1. Alfaro, A., and Silvan, A. 1940. La "tabaquera" de las judías. Bol. Patol. Veg. Entomol. Agríc. 9:9-20.

2. Audy, P., Laroche, A., Saidon, G., Huang, H. C., and Gilbertson, R. L. 1994. Detection of the bean common blight bacteria, Xanthomonas campestris pv. phaseoli and X. c. phaseoli var. fuscans, using the polymerase chain reaction. Phytopathology 84:1185-1192.

3. Balardin, R. S., Jarosz, A. M., and Kelly, J. D. 1997. Virulence and molecular diversity in Colletotrichum lindemuthianum. Phytopathology 87:1184-1191.

4. Barak, J. D., and Gilbertson, R. L. 2003. Genetic diversity of Xanthomonas campestris pv. vitians, the causal agent of bacterial leafspot of lettuce. Phytopathology 93:596-603.

5. Birch, P. R. J., Hyman, L. J., Taylor, R., Opio, A. F., Bragard, C., and Toth, I. K. 1997. RAPD PCR-based differentiation of Xanthomonas campestris pv. phaseoli and Xanthomonas campestris pv. phaseoli var. fuscans. Eur. J. Plant Pathol. 103:809-814.

6. Bouzar, H., Jones, J. B., Stall, R. E., Louws, F. J., Schneider, J. L., Rademaker, J. L. W., de Bruijn, F. J., and Jackson, L. E. 1999. Multiphasic analysis of xanthomonads causing bacterial spot disease on tomato and pepper in the Caribbean and Central America: Evidence for common lineages within and between countries. Phytopathology 89:328-335.

7. Chan, J. W. Y. F., and Goodwin, P. H. 1999. Differentiation of Xanthomonas campestris pv. phaseoli from Xanthomonas campestris pv. phaseoli var. fuscans by PFGE and RFLP. Eur. J. Plant Pathol. 105:867-878.

8. Coyne, D. P., Steadman, J. R., Godoy-Lutz, G., Gilbertson, R., ArnaudSantana, E., Beaver, J. S., and Myers, J. R. 2003. Contributions of the Bean/Cowpea CRSP to management of bean diseases. Field Crops Res. $82: 155-168$.

9. Dye, D. W. 1962. The inadequacy of the usual determinative tests for the identification of Xanthomonas spp. N.Z. J. Sci. 5:393-416.

10. Ekpo, E. J. A., and Saettler, A. W. 1976. Pathogenic variation in Xanthomonas phaseoli and Xanthomonas phaseoli var. fuscans. Plant Dis. Rep. 60:80-83.

11. Gent, D. H., Al-Saadi, A., Gabriel, D. W., Louws, F. J., Ishimaru, C. A., and Schwartz, H. F. 2005. Pathogenic and genetic relatedness among Xanthomonas axonopodis pv. allii and other pathovars of $X$. axonopodis. Phytopathology 95:918-925.

12. Gepts, P. 1998. Origin and evolution of common bean: Past events and recent trends. HortScience 33:1124-1130.

13. Gilbertson, R. L., and Maxwell, D. P. 1992. Common blight of beans. Pages 18-39 in: Diseases of International Importance. H. S. Chaube, U.S. Singh, and A. N. Mukhopadhay, eds. Prentice Hall, Inglewood Cliffs, NJ.

14. Gilbertson, R. L., Maxwell, D. P., Hagedorn, D. J., and Leong, S. A. 1989. Development and application of a plasmid DNA probe for detection of bacteria causing common bacterial blight of bean. Phytopathology 79:518-525.

15. Gilbertson, R. L., Otoya, M. M., Pastor-Corrales, M. A., and Maxwell, D. P. 1991. Genetic diversity in common blight bacteria is revealed by cloned repetitive DNA sequences. Annu. Rep. Bean Improv. Coop. 34:37-38.

16. Goodwin, P. H., and Sopher, C. R. 1994. Brown pigmentation of Xanthomonas campestris pv. phaseoli associated with homogentisic acid. Can. J. Microbiol. 40:28-34.
17. Guzmán, P., Gilbertson, R. L., Nodari, W. C., Johnson, W. C., Temple, S. R., Mandala, D., Mkandawire, A. B. C., and Gepts, P. 1995. Characterization of variability in the fungus Phaeoisariopsis griseola suggest coevolution with the common bean (Phaseolus vulgaris). Phytopathology 85:600-607.

18. Hayward, A. C., and Waterston, J. M. 1965. Xanthomonas phaseoli. No. 48 and Xanthomonas phaseoli var. fuscans. No. 49 in: CMI Descriptions of Pathogenic Fungi and Bacteria. Commonw. Mycol. Inst./Assoc. Appl. Biol., Kew, England.

19. Hildebrand, D. C., Palleroni, N. J., and Schroth, M. N. 1990. Deoxyribonucleic acid relatedness of 24 xanthomonad strains representing 23 Xanthomonas campestris pathovars and Xanthomonas fragariae. J. Appl. Bacteriol. 68:263-269.

20. Lazo, G. R., Robin, R., and Gabriel, D. W. 1987. Pathovars of Xanthomonas campestris are distinguishable by restriction fragment-length polymorphism. Int. J. Syst. Bacteriol. 37:214-221.

21. Leaky, C. L. A. 1973. A note on Xanthomonas blight of beans (Phaseolus vulgaris (L.) Savi) and prospects for its control by breeding for tolerance. Euphytica 22:132-140.

22. Louws, F. J., Fulbright, D. W., Stephens, C. T., and de Bruijn, F. J. 1994. Specific genomic fingerprints of phytopathogenic Xanthomonas and Pseudomonas pathovars and strains generated with repetitive sequences and PCR. Appl. Environ. Microbiol. 60:2286-2295.

23. Louws, F. J., Fulbright, D. W., Stephens, C. T., and de Bruijn, F. J. 1995. Differentiation of genomic structure by rep-PCR fingerprinting to rapidly classify Xanthomonas campestris pv. vesicatoria. Phytopathology 85:528536.

24. Louws, F. J., Rademaker, J. L. W., and de Bruijn, F. J. 1999. The three Ds of PCR-based genomic analysis of phytobacteria: Diversity, detection, and disease diagnosis. Annu. Rev. Phytopathol. 37:81-125.

25. Mahuku, G. S., Henriquez, M. A., Munoz, J., and Buruchara, R. A. 2002. Molecular markers dispute the existence of the Afro-Andean group of the bean angular leafspot pathogen, Phaeoisariopsis griseola. Phytopathology 92:580-589.

26. Mkandawire, A. B. C., Mabagala, R. B., Guzmán, P., Gepts, P., and Gilbertson, R. L. 2004. Genetic diversity and pathogenic variation of common blight bacteria (Xanthomonas campestris pv. phaseoli and Xanthomonas campestris pv. phaseoli var. fuscans) suggests pathogen coevolution with the common bean. Phytopathology 94:593-603.

27. NTSYSpc. 2000. Numerical Taxonomy and Multivariate Analysis System User's Guide. Exeter Software, Setauket, NY.

28. Opio, A. F., Allen, D. J., and Teri, J. M. 1996. Pathogenic variation in Xanthomonas campestris pv. phaseoli, the causal agent of common bacterial blight in Phaseolus beans. Plant Pathol. 45:1126-1133.

29. Pastor-Corrales, M., Beebe, S., and Correa, F. J. 1981. Comparing two inoculation techniques for evaluating resistance in beans to Xanthomonas campestris pv. phaseoli. Pages 493-503 in: Proc. Fifth Int. Conf. PlantPathogenic Bacteria. J. C. Lozano, ed. CIAT, Cali, Colombia.

30. Pastor-Corrales, M. A. 1996. Traditional and molecular confirmation of the coevolution of beans and pathogens in Latin America. Annu. Rep. Bean Improv. Coop. 39:46-47

31. Pastor-Corrales, M. A., and Aime, M. C. 2004. Differential cultivars and molecular markers segregate isolates of Uromyces appendiculatus into two distinct groups that correspond to the gene pools of their common bean hosts. (Abstr.) Phytopathology 94:S82.

32. Rademaker, J. L. W., and de Brujin, F. J. 1997. Characterization and classification of microbes by rep-PCR genomic fingerprinting and computer assisted pattern analysis. Pages 151-171 in: DNA Markers: Protocols, Applications and Overviews. G. Caetano-Anolles and P. M. Gresshoff, eds. John Wiley \& Sons, New York.

33. Rademaker, J. L. W., Hoste, B., Louws, F. J., Kersters, K., Swings, J., Vauterin, L., Vauterin, P., and de Bruijn, F. J. 2000. Comparison of AFLP and rep-PCR genomic fingerprinting with DNA-DNA homology studies: Xanthomonas as a model system. Int. J. Syst. Evol. Microbiol. 50:665677.

34. Rademaker, J. L. W., Louws, F. J., Schultz, M. H., Rossbach, U., Vauterin, L., Swings, J., and de Bruijn, F. J. 2005. A comprehensive species to strain taxonomic framework for Xanthomonas. Phytopathology 95:1098-1111.

35. Rava, C. A., and Romeiro, R. S. 1990. Variability among isolates of Xanthomonas campestris pv. phaseoli in relation to their pathogenicity on Phaseolus vulgaris cultivars. Summa Phytopathol. 16:225-232.

36. Sabet, K. A. 1959. Studies in the bacterial diseases of Sudan crops. III. On the occurrence, host range and taxonomy of bacteria causing leaf blight diseases of certain leguminous hosts. Ann. Appl. Biol. 47:318-331.

37. Sandlin, C. M., Steadman, J. R., and Araya, C. M. 1999. Isolates of Uromyces appendiculatus with specific virulence to landraces of Phaseolus vulgaris of Andean origin. Plant Dis. 83:108-113.

38. Santalla, M., Rodiño, A. P., and de Ron, A. M. 2002. Allozyme evidence supporting southwestern Europe as a secondary center of genetic diversity for the common bean. Theor. Appl. Genet. 104:934-944. 
39. SAS Institute. 1999. SAS/STAT User's Guide. SAS Institute, Inc., Cary, NC.

40. Schaad, N. W., Jones, J. B., and Chun, W. 2001. Laboratory Guide for Identification of Plant-Pathogenic Bacteria, 3rd ed. The American Phytopathological Society, St. Paul, MN.

41. Schuster, M. L. 1955. A method for testing resistance of beans to bacterial blight. Phytopathology 45:519-520.

42. Schuster, M. L. 1983. Variability in virulence of Dominican Republic Xanthomonas phaseoli in CIAT Phaseolus vulgaris cultivars. Fitopatol. Bras. 8:339-345.

43. Schuster, M. L., and Coyne, D. P. 1971. New virulent strains of Xanthomonas phaseoli. Plant Dis. Rep. 55:505-506.

44. Schuster, M. L., and Coyne, D. P. 1977. Characterization and variation of Xanthomonas and Corynebacterium incited diseases of beans (Phaseolus vulgaris L.). Fitopatol. Bras. 2:200-207.

45. Schuster, M. L., Coyne, D. P., and Hoff, B. 1973. Comparative virulence of Xanthomonas phaseoli strains from Uganda, Colombia, and Nebraska. Plant Dis. Rep. 57:74-75.

46. Shiotani, H., Ozaki, K., and Tsuyumu, S. 2000. Pathogenic interactions between Xanthomonas axonopodis pv. citri and cultivars of pummelo (Citrus grandis). Phytopathology 90:1383-1389.

47. Sicard, D., Michalakis, Y., Dron, M., and Neema, C. 1997. Genetic diversity and pathogenic variation of Colletotrichum lindemuthianum in the centers of diversity of its host, Phaseolus vulgaris. Phytopathology $87: 807-813$.
48. Valladares-Sanchez, N. E., Coyne, D. P., and Schuster, M. L. 1979. Differential reaction of leaves and pods of Phaseolus germplasm to strains of Xanthomonas phaseoli and transgressive segregation for tolerance from crosses of susceptible germplasm. J. Am. Soc. Hortic. Sci. 104:648-654.

49. Vauterin, L., Rademarker, J., and Swings, J. 2000. Synopsis on the taxonomy of the genus Xanthomonas. Phytopathology 90:677-682.

50. Vidaver, A. K. 1993. Xanthomonas campestris pv. phaseoli: Cause of common bacterial blight of bean. Pages 40-44 in: Xanthomonas. J. G. Swings and E. L. Civerolo, eds. Chapman \& Hall, London.

51. Yap, V. I., and Nelson, J. R. 1996. WinBoot: A program for performing bootstrap analysis of binary data to determine confidence limits of UPGMA-based dendrograms. IRRI (Int. Rice Res. Inst.) Res. Pap. Ser. No. 14.

52. Yoshii, K., Galvez-E., G. E., and Alvarez-A., G. 1978. Screening bean germplasm for tolerance to common blight caused by Xanthomonas phaseoli and the importance of pathogenic variation to varietal improvement. Plant Dis. Rep. 62:343-347.

53. Zaiter, H. Z., Coyne, D. P., Vidaver, A. K., and Steadman, J. R. 1989. Differential reaction of tepary bean lines to Xanthomonas campestris pv. phaseoli. HortScience 24:134-137.

54. Zaumeyer, W. J., and Thomas, H. R. 1957. A monographic study of bean diseases and methods for their control. U.S. Dep. Agric. Tech. Bull. 868 . 